\title{
Keragaman dan Potensi Makrofungi di Obyek Ekowisata Kaki Dian, Gunung Klabat-Minahasa Utara
}

\section{Diversity and Potency of Macrofungi in Kaki Dian Ecotourism Object of Klabat Mount - North Minahasa}

\author{
Christita M, Arini DID, Kinho J, Halawane JE, Kafiar J, Diwi MS
}

Balai Penelitian dan Pengembangan Lingkungan Hidup dan Kehutanan Manado, Sulawesi Utara 95259

Christita M, Arini DID, Kinho J, Halawane JE, Kafiar J, Diwi MS. 2017- Keragaman dan Potensi Makrofungi di Obyek Ekowisata Kaki Dian, Gunung Klabat-Minahasa Utara. Jurnal Mikologi Indonesia 1(2), 82-95.

\begin{abstract}
Abstrak
Keanekaragaman makrofungi sangat menarik untuk diamati, sayangnya informasi keragaman makrofungi di wilayah Wallacea sangat terbatas. Tujuan penelitian ini adalah untuk mengetahui keragaman makrofungi dan potensi peluang penggunaannya di kawasan ekowisata Kaki Dian Gunung Klabat, Minahasa Utara. Kawasan ekowisata Kaki Dian Gunung Klabat lebih dipilih karena memiliki keanekaragaman hayati khas bioregion Wallacea dan memiliki banyak pengunjung yang datang untuk menikmati pemandangan alam. Metode yang digunakan dalam penelitian ini adalah metode eksplorasi di sepanjang jalur pendakiandi kawasan ekowisata Kaki Dian, Utara Minahasa, Sulawesi Utara. Pengamatan dan identifikasi dilakukan berdasarkan karakteristik macrofungi antara lain: warna, diameter, bentuk tudung, bentuk batang, panjang dan diameter batang, ada tidaknya lamella atau pori dan cincin, jenis lamella dan jenis volva, serta habitat dan potensi pemanfaatannya. Data dianalisis secara deskriptifkualitatif. Sebanyak 61 spesies jamur makroskopik yang termasuk ke dalam pembagian ascomycota dan basidiomycota. Spesies ini termasuk dalam 23 famili, 7 ordo. Berdasarkan tempat tumbuh, 92\% ditemukan tumbuh pada kayu yang membusuk dan $8 \%$ ditemukan tumbuh di tanah atau sarasah. Berdasarkan potensi penggunaannya, 3 jenis memiliki potensi industri, 10 jenis diidentifikasi sebagai jamur pangan dan 11 jenis diidentifikasi sebagai jamur berpotensi obat.
\end{abstract}

Kata kunci- Keragaman, Jamur Pangan, Jamur obat, Makrofungi, Minahasa

\begin{abstract}
Macrofungi diversity is interested to observe, unfortunately the information on macrofungi diversity in the Wallacea region was very limited. This research purposes are to identify the fungal species diversity and its potential usage opportunities in the Kaki Dian Ecoturism Object of Mount Klabat, North Minahasa. Kaki Dian Ecotourism Object of Mount Klabat was preferred since it holds the biodiversity typical of Wallace bargain and it has many visitors come to enjoy nature view. The methods used in this research were cruise method along the hiking trail at Kaki Dian Ecoturism Object of Mount Klabat-North Minahasa region, North Sulawesi. Observation and identification were conducted based on macrofungal characteristics, including: the color, diameter, surface of the veil, the shape of the
\end{abstract}


stem, the length and diameter of the stem, the presence or absence of lamella or porous and ring, type of lamella and the type of valve, as well as their habitat and potential utilization. Data were analyzed descriptively-qualitatively. The results of the research were identified 61 species of microscopic fungi that included in the division of the Ascomycota and Basidiomycota. These species belong to 23 families, 7 orders. According to based place to grow, $92 \%$ were found growing on decaying wood and $8 \%$ were found growing in the soil or litter. Based on its potential opportunities, 3 types have industrial use, 10 types were identified as edible mushroom and 11 types were identified as medicinal fungi.

Key words - Biodiversity, Edible, Macrofungi, Medicinal, Minahasa

\section{Pendahuluan}

Keragaman makrofungi sangat menarik untuk dipelajari. Dalam dunia makhluk hidup, fungi menempati urutan kedua sebagai organisme terbesar yang ada di bumi setelah serangga (Li et al. 2012). Makrofungi merupakan jamur yang memiliki tubuh buah yang cukup besar dan dapat dilihat dengan mata telanjang. Tubuh buah jamur, umumnya berbentuk payung (ada juga yang berbentuk mangkuk, kuping, setengah lingkaran dan bulat) dan mempunyai akar semu (rhizoids), batang (stipe), tudung (pileus), bilah (lamella) kadang disertai cincin (annulus) dan cawan (volva) (Sinaga 2005). Sebagai bagian dari ekosistem hutan tropis Indonesia, fungi memiliki fungsi sebagai dekomposer bersama dengan bakteri sehingga banyak membantu proses dekomposisi bahan organik untuk mempercepat siklus karbon dalam ekosistem hutan (Van der Wal et al. 2012).

Makrofungi dengan mudah ditemukan di berbagai tipe bioregion, salah satunya adalah bioregion Wallacea yang dikenal memiliki tingkat keragaman hayati yang sangat tinggi. Sulawesi Utara merupakan bagian dari kawasan bioregion Wallacea yang menyimpan begitu banyak keragaman hayati, salah satunya adalah keragaman jenis makrofungi, namun demikian potensi ini belum banyak diteliti dan dipublikasikan. Arini dan Christita (2016) mengidentifikasi 29 jenis makrofungi di Gunung Ambang, Sulawesi Utara.

Penelitian ini dilakukan di obyek wisata Kaki Dian yang merupakan salah satu obyek wisata alam yang berada di Kaki Gunung Klabat, Kabupaten Minahasa Utara, Sulawesi Utara. Udara di Kaki Gunung Klabat cukup sejuk bervariasi anatara 25,5 hingga $27^{\circ} \mathrm{C}$ pada pagi hingga siang hari, dengan kelembaban sekitar $85 \%$. Obyek wisata Kaki Dian berada pada ketinggian 510-560 mdpl. Dengan kondisi suhu, kelembaban dan ketinggian tempat tersebut, diperkirakan berbagai jenis makrofungi dapat tumbuh dengan baik. Hingga saat ini belum pernah dilakukan identifikasi jenis-jenis makrofungi yang berada di kawasan obyek wisata Kaki Dian, Gunung Klabat.

Tujuan penelitian ini adalah untuk mengidentifikasi spesies makrofungi yang terdapat di obyek wisata Kaki Dian, Kaki Gunung Klabat, Minahasa Utara sekaligus melakukan identifikasi terhadap tempat tumbuh dan potensinya.

\section{Metode Penelitian \\ Lokasi Penelitian}

Obyek wisata Kaki Dian yang berada di Kaki Gunung Klabat, Lingkungan IV, Kelurahan Airmadidi Atas, Kecamatan Airmadidi, Kabupaten Minahasa Utara. Lokasi penelitian memiliki ketinggian 510-560 mdpl. Lokasi penelitian seluas tiga hektar.

\section{Eksplorasi den identifikasi}

Pengumpulan data jenis jamur dilakukan dengan metode ekplorasi yaitu jelajah secara acak terwakili. Pengambilan sampel dilakukan sepanjang jalur jelajah. Pengambilan dokumentasi dilakukan di lapangan pada posisi awal sebelum makrofungi diambil sebagai sampel. Identifikasi dilakukan dengan pengamatan makroskopis makrofungi meliputi bentuk 
dan warna tudung, permukaan tudung, tipe tudung, diameter tudung, bentuk tangkai, panjang dan diameter tangkai, ada atau tidaknya lamella atau porus dan cincin, tipe lamella serta tipe volva.

Identifikasi makrofungi dilakukan secara manual dengan metode konvensional yaitu mencocokkan hasil pengamatan karakteristik makrofungi dengan pustaka antara lain Boa (2004), First nature (2014), Charlie et al, (2004), Holmberg \& Marklund (1996), Karhonen (2016), dan Kosonen (1994). Hasil identifikasi dikelompokkan berdasarkan taksonomi meliputi divisi, kelas, ordo, famili dan spesies.

Selain jenis dicatat pula tempat tumbuhnya. Pengumpulan data pendukung berupa ketinggian, suhu, dan kelembaban dicatat sebagai data primer. Data pendukung berupa suhu dan kelembaban selama tujuh hari pengamatan dilakukan setiap jam dimulai dari jam 06.00 WITA dan diakhiri pada 18.00 WITA, data selama satu minggu dikompilasi menjadi data rata-rata suhu dan kelembaban harian. Penelitian dilakukan pada bulan selama satu minggu pada bulan Februari 2017.

\section{Hasil}

Berdasarkan hasil observasi dapat didentifikasi 61 jenis jamur yang berbeda dan temasuk ke dalam 2 divisi yaitu ascomycota dan basidomycota. Sebanyak tiga famili termasuk kedalam divisi ascomycota yaitu Morchellaceae, Sacoscyphaceae dan Xylariaceae, sementara divisi basidiomycota terbagi menjadi 20 jenis famili (Tabel 1). Keragaman jenis ini didominasi oleh makrofungi dari ordo Agaricales.

Tabel 1. Makrofungi yang ditemukan di Obyek Wisata Kaki Dian

\begin{tabular}{|c|c|c|c|c|}
\hline Divisi & Kelas & Ordo & Famili & Spesies \\
\hline \multirow[t]{2}{*}{ Ascomycota } & Pezizomycetes & Pezizales & $\begin{array}{l}\text { Morchellaceae } \\
\text { Sarcoscyphaceae }\end{array}$ & $\begin{array}{l}\text { Morchella } \mathrm{sp} . \\
\text { Sarcoschypa } \mathrm{sp} . \\
\text { Philapsia } \\
\text { domingensis }\end{array}$ \\
\hline & Sordariomycetes & Xylariales & Xylariaceae & $\begin{array}{l}\text { Xylaria hypoxylon } \\
\text { Xylaria polymorpha } \\
\text { Xylaria } \mathrm{sp} .1 \\
\text { Xylaria } \mathrm{sp} .2\end{array}$ \\
\hline \multirow[t]{7}{*}{ Basidiomycota } & Agaricomycetes & Agaricales & Auriculariaceae & $\begin{array}{l}\text { Auricularia sp.1 } \\
\text { Auricularia sp. } 2 \\
\text { Auricularia sp. } 3 \\
\text { Auricularia } \\
\text { auricula-judae } \\
\text { Auricularia sp.4 } \\
\text { Clavulinopsis } \\
\text { laeticolor }\end{array}$ \\
\hline & & & Crepidotaceae & $\begin{array}{l}\text { Crepidotus } \mathrm{sp} 1 \\
\text { Crepidotus } \mathrm{sp} .2 \\
\text { Crepidotus } \\
\text { appalanatus }\end{array}$ \\
\hline & & & Entolomataceae & Entoloma sp. \\
\hline & & & Hymenogastraceae & Galerina sp \\
\hline & & & Mycenaceae & Mycena sp. 1 \\
\hline & & & Psathyrellaceae & $\begin{array}{l}\text { Coprinopsis sp. } \\
\text { Parasola plicatilis } \\
\text { Coprinellus sp. } \\
\text { Parasola } \\
\text { leiocephala }\end{array}$ \\
\hline & & & Strophariaceae & $\begin{array}{l}\text { Hypholoma sp. } \\
\text { Gymnopilus sp. } 1\end{array}$ \\
\hline
\end{tabular}




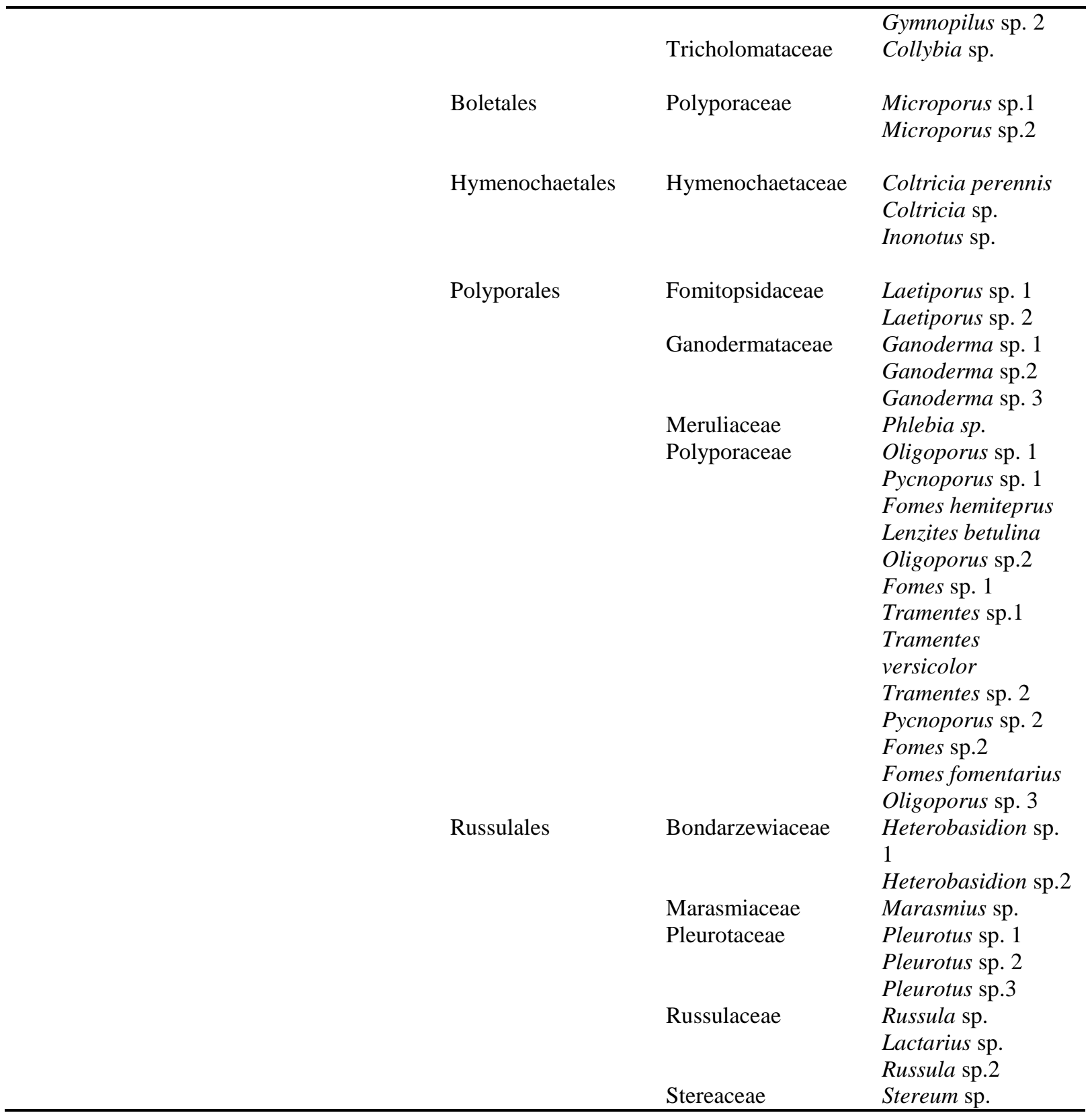

Berdasarkan media tumbuhnya, makrofungi di kawasan wisata Kaki Dian terbagi menjadi 2 yaitu makrofungi yang tumbuh di batang pohon sebanyak 56 jenis dan tumbuh di tanah atau serasah terdiri atas sebanyak 5 jenis. Makrofungi yang tumbuh di tanah yaitu Entoloma sp., Parasola plicatilis, Parasola leiocephala, Morchella sp. dan Hypholoma sp..

Hasil penelitian mengidentifikasi sebanyak 11 species memiliki potensi sebagai jamur obat (medicinal fungi) antara lain Ganoderma spp dan Xylaria hypoxylon, 3 species berpotensi dikembangkan dalam bidang industri yaitu Phlebia sp., Pycnoporus sp.1, dan Pycnoporus sp.2. Sedangkan 10 species berpotensi sebagai jamur pangan (edible fungi) antara lain Pleurotus spp dan Auricularia spp, sementara sisanya belum teridentifikasi (Tabel 2.)

Berdasarkan pengukuran data primer meliputi suhu dan kelembaban udara serta ketinggian tempat di beberapa titik tumbuh makrofungi, diketahui bahwa kawasan obyek wisata Kaki Dian memilikisuhu harian rata-rata $26,7{ }^{\circ} \mathrm{C}$ dengan kelembaban harian rata-rata 82,6. Pengukuran dilakukan setiap dua jam diwali pada pukul 06.00 WITA dan diakhiri pada 
pukul 18.00 WITA. Pengambilan sampel dilakukan pada beberapa ketinggian mengikuti jalur ekplorasi yang berkisar antara $510 \mathrm{~m}$ dpl hingga $560 \mathrm{mdpl}$.

Tabel 2. Rata-rata suhu dan kelembaban harian

\begin{tabular}{lccc}
\hline & & \multicolumn{2}{c}{ Rata-rata } \\
\cline { 3 - 4 } Waktu & Ketinggian & Suhu $^{\circ} \mathrm{C} *$ & Kelembaban\%* \\
\hline 06.00 & 510 & 25 & 86 \\
08.00 & 525 & 26 & 85 \\
10.00 & 560 & 26 & 82 \\
12.00 & 550 & 28 & 83 \\
14.00 & 530 & 28 & 80 \\
16.00 & 520 & 27 & 80 \\
18.00 & 510 & 27 & 82 \\
\hline & rata-rata** & 26,7 & 82,6 \\
\hline
\end{tabular}

ket : ${ }^{*}=$ hasil perhitungan rata-rata selama 7 hari pengamatan pada jam yang sama.

$* *=$ hasil perhitungan rata-rata harian

\section{Pembahasan}

Fungi merupakan mikroba heterotropik yang memiliki variasi luas dalam hal bentuk, struktur dan ukurannya (Hanafiah 2005). Makrofungi atau lebih dikenal dengan cendawan merupakan jenis fungi yang memiki badan buah makroskopis, dengan ukuran yang bervariasi. Berdasarkan hasil identifikasi, komposisi keragaman jenis makrofungi di kawasan wisata Kaki Dian didominasi oleh ordo Agaricales dari divisi basidiomycota. Ordo Agaricales merupakan ordo yang sangat umum dijumpai di hutan-hutan tropis. Hal ini senada dengan penelitian keragaman makrofungi di Cagar Alam Gunung Ambang yang dilakukan oleh Arini dan Christita (2016) telah mengidentifikasi 26 species makrofungi yang juga didominasi oleh ordo Agaricales. Sementara pada divisi Ascomycota dijumpai tujuh species berbeda yang didominasi oleh spesies yang berasal dari famili Xylariacea.

Berdasarkan observasi lapangan dan identifikasi yang telah dilakukan dapat dijelaskan bahwa makrofungi yang dijumpai di kawasan wisata Kaki Dian, Kaki Gunung Klabat, Minahasa Utara mempunyai peluang dan potensi yang besar untuk dapat dikembangkan dan dibudidayakan sebagai jamur pangan, jamur berpotensi obat dan industri. Keberadaan makrofungi sebagai hasil hutan bukan kayu memiliki potensi tinggi yang dapat dikembangkan sebagai sumber pangan, dan bahan baku obat (Prasetyaningsih dan Raharjo 2015). Waenberg et al. 2003 menyebutkan bahwa ada potensi dalam dunia industri dengan pemanfaatan enzim yang dihasilkan oleh makrofungi. Beberapa jenis jamur yang belum teridentifikasi hingga tingkat species dan belum dapat teridentifikasi potensinya merupakan peluang untuk penelitian lebih lanjut di masa yang akan datang. Pada penelitian ini berhasil diidentifikasi sebanyak 10 jenis merupakan jamur berpotensi sebagai bahan makanan antara lain jenis-jenis jamur tiram, jamur kuping. Berdasarkan penelitian Christita (2016) jamur tiram putih (Pleurotus ostreatus) merupakan jamur pangan yang cocok dibudidayakan dengan media sabut kelapa, sehingga dapat dikembangkan sbagai alternatif pangan di Sulawesi Utara yang kaya potensi sabut kelapa.

Bangsa Cina telah mengawali pengobatan tradisional dengan memanfaatkan jamur yang tumbuh secara liar hutan. Ganoderma sp., yang dikenal sebagi jamur ling zhi telah digunakan dalam pengobatan raja dan bangsawan pada jaman Dinasti Shu sekitar 2400 tahun yang lalu (Sa'id et al. 2012). Hingga saat ini penelitian manfaat genus Ganoderma sebagai bahan dasar pada industri obat terus dilakukan. Dalam dunia farmakologi, Ganoderma 
lucidum telah terbukt efektif memiliki zat anti tumor dan immuno modulating (Zhou et al, 2007). Pada penelitian ini dijumpai famili Ganodermataceae yang terbagi menjadi tiga jenis species yang berbeda berdasarkan karakteristik makroskopis yang diamati yaitu Ganoderma sp.1, Ganoderma sp.2, dan Ganoderma sp.3. Terdapat jenis Ganoderma yang menurut penelitian merupakan jamur berpotensi obat, menurut masyarakat dapat dimanfaatkan sebagai bahan makanan.

Pada penelitian ini juga ditemukan makrofungi berpotensi industri yaitu Pygnoporus spp. dan Phlebia sp. Berdasarakan penelitian Uzan et al. (2010) dan Ramirez et al. (2014), Pycnoporus memiliki potensi yang besar untuk dikembangkan pada industri bioteknologi dengan memanfaatkan keberlimpahan enzim laccase. Beberapa species pada genus Xylariaceae juga telah terbukti menghasilkan enzim pendegradasi lignin dalam jumlah yang melimpah (Pointing et al 2003). Chander and Arora (2005) mendapatkan hasil penelitian bahwa Tramentes versicolor, yang selama ini dikenal sebagai jamur patogen yang menyebabkan karat putih pada pohon (white rot fungi) memiliki potensi yang besar untuk dikembangkan dalam industri pewarna karena kemampuannya mendegradasi lignin.

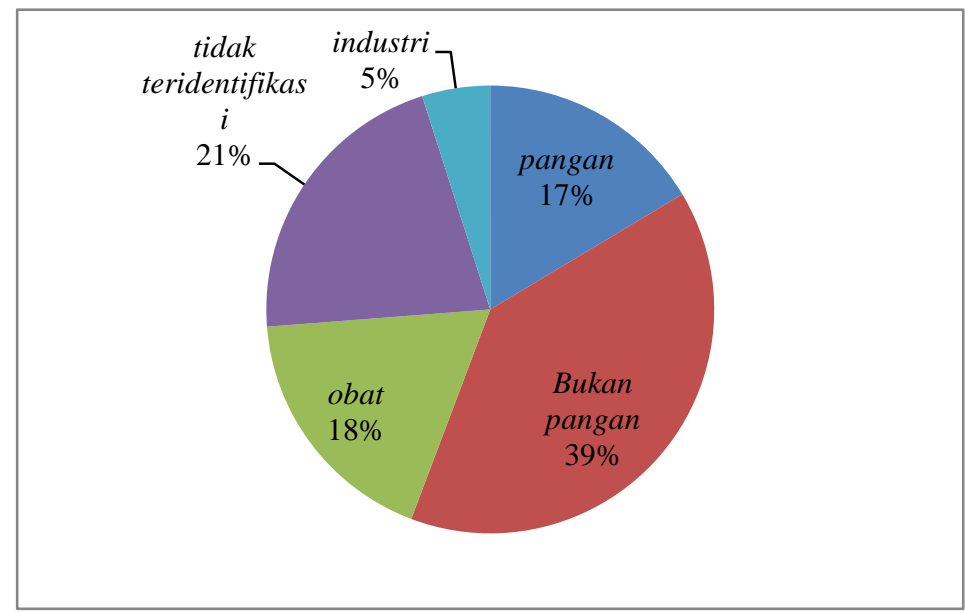

Gambar 2. Potensi pemanfaatan makrofungi di obyek wisata Kaki Dian

Makrofungi yang dijumpai di kawasan wisata Kaki Dian, Kaki Gunung Klabat, Minahasa Utara $92 \%$ tumbuh pada media batang pohon atau kayu lapuk dan sisanya sebanyak $8 \%$ tumbuh pada media tanah atau serasah. Tanah merupakan media tumbuh yang memiliki zat penting yang dibutuhkan tumbuhan untuk metabolisme meliputi unsur-unsur hara baik mikro dan makro serta adanya aktivitas biota tanah sebagai penunjang kehidupan tumbuhan di tanah (Hanafiah 2005). Makrofungi selain membutuhkan zat hara juga memerlukan lignin dan selulosa untuk hidup dan melakukan metabolismenya sehingga lebih banyak dijumpai makrofungi yang tumbuh di batang pohon dan kayu lapuk. Jamur yang tumbuh pada tanah memiliki fungsi penting dalam daur ekologis dan biokimia tanah. Kemampuan fungi membentuk miselium dan memproduksi enzim bahkan mampu memanfaatkan logam-logam polutan pada tanah untuk pertumbuhannya sehingga secara biokimia fungi mampu mengurangi tingkat polutan pada tanah (Harms et al. 2011). Tidak hanya mampu tumbuh pada tanah yang subur, makrofungi juga ditemukan di kawasan perkebunan hingga daerah bekas lahan yang pernah terbakar (Sysouphanthonget al. 2010).

Pencatatan data primer berupa ketinggian tempat, suhu dan kelembaban udara sangat penting karena pertumbuhan makrofungi sangat dipengaruhi oleh faktor lingkungan tersebut. Beberapa jenis jamur berpotensi pangan diketahui dapat tumbuh dengan baik pada kelembaban sekitar 60\%-80\%, pada ketinggian 500 hingga 600 mdpl (Sa'id et al. 2012). Beberapa penelitian ada jamur budidaya menunjukkan bahwa jamur tiram tidak dapat 
menghasilkan tubuh buah yang baik jika kondisi lingkungan terlalu kering, namun juga jika lingkungan terlalu basah maka jamur akan rentan terserang penyakit. Berdasarkan data tersebut dapat disimpulkan bahwa kondisi lingkungan di obyek wisata Kaki Dian, Gunung Klabat, Minahasa Utara sangat sesuai dan mampu memberikan daya dukung untuk pertumbuhan dan metabolisme makrofungi.

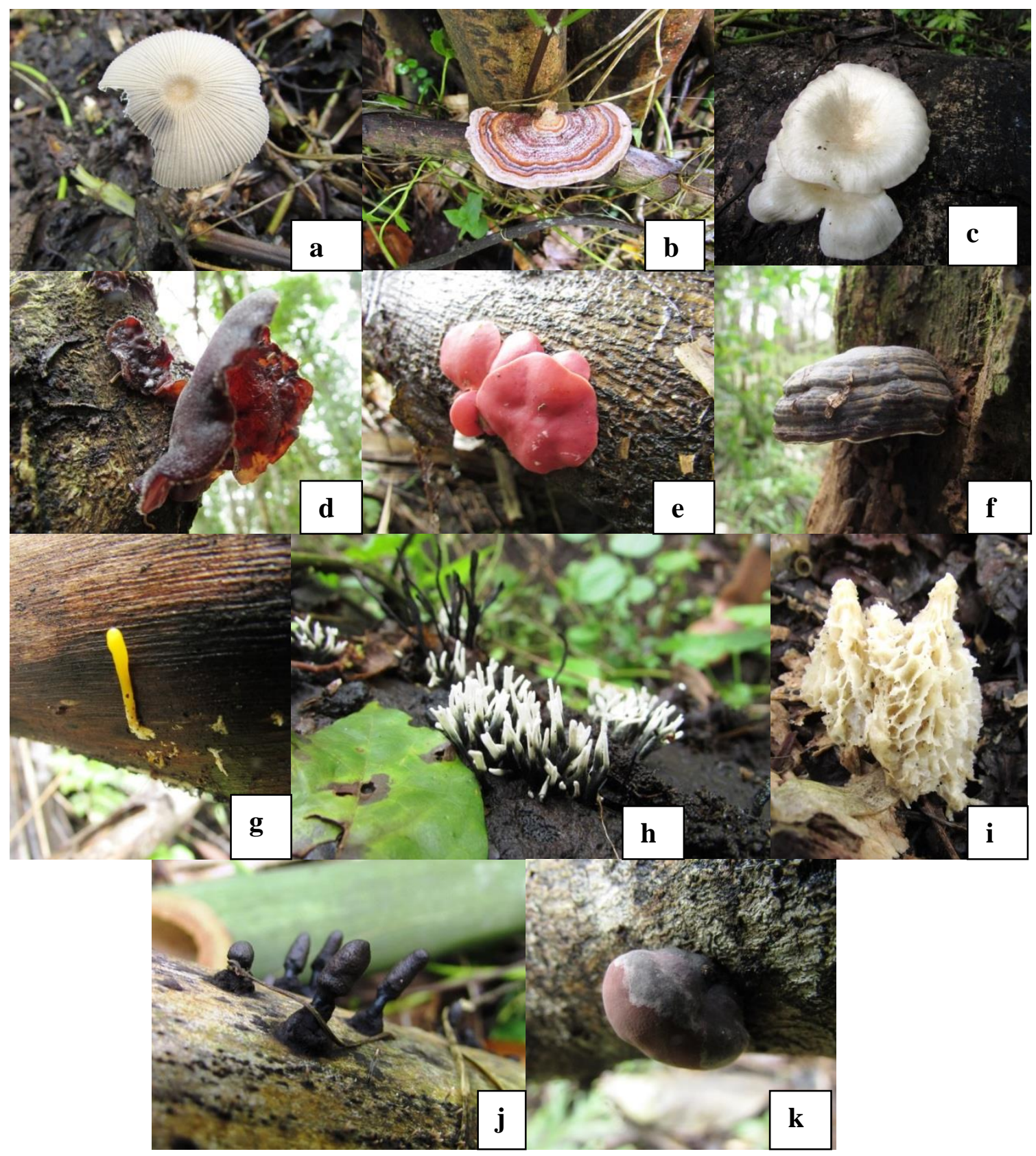

Gambar 3. a) Parasola sp.; b) Tramentes versicolor; c) Pleurotus sp.; d) Auricularia sp.; e) Sarcoshypa sp.; f) Fomes fomentarius; g) Xylaria sp.; h) Xylaria hypoxylon; i) Morchella sp.; i) Xylaria polymorpha; j) Xylaria polymorphak; k) Fomes sp..

Penelitian ini memiliki keterbatasan dalam hal identifikasi hasil eksplorasi jamur dilapangan karena tidak dilakukan hingga taraf molekuler, sehingga identifikasi sebagian besar makrofungi hanya pada tingkat famili. Makrofungi yang belum teridentifikasi akan dilanjutkan perlakuan identifikasi secara molekuler. 
Sebagai salah satu bagian dari bioregion wallacea, obyek wisata Kaki Dian di Kaki Gunung Klabat, Minahasa Utara memiliki potensi keragaman makrofungi sebanyak 61 jenis dengan potensi sebagai jamur pangan, jamur bahan obat, dan jamur potensi industri. Keragaman makrofungi dan pertumbuhan tubuh buah makrofungi yang baik di obyek wisata Kaki Dian, Kaki Gunung Klabat, Minahasa Utara didukung oleh faktor lingkungan berupa kelembaban dan suhu udara yang sesuai serta ketinggian tempat yang cocok sebagai habitat makrofungi.

\section{Ucapan Terima Kasih}

Penulis mengucapkan terimakasih kepada LPPT Manado, Pemda Minahasa Utara dan Balai Penelitian dan Pengembangan Lingkungan Hidup dan Kehutanan Manado, atas kesempatan untuk melakukan penelitian ini. Penulis juga mengucapkan apresiasi setinggitingginya kepada teknisi yang membantu pekerjaan di lapangan pada penelitian ini.

\section{Pustaka}

Arini, DID, Christita M. 2016. Keanekaragaman Makrofungi Di Cagar Alam Gunung Ambang Sulawesi Utara Dan Peluang Potensinya. [Prosiding] Seminar Nasional Biodiversitas VI, 49-59.

Boa, E. (2004). Wild Edible Fungi : A Global Overview of Their Use and Importance for People. Rome: FAO.

Chander M, Arora DS. 2005. Evaluation of Some White-Rot Fungi for Their Potential to Decolourise Industrial Dyes. Dyes and Pigments XX, 1-7.

Carlile, M. J., S.C. Watkinson,. \& G.W. Gooday. (2004). The Fungi. London: Academic Press.

Christita, Margaretta, Suryawan A, Irawan A, Tabba S, and Mokodompit HS.2016. The Suitability of Agroforestry Waste as Cultivation Media for White Oyster Mushroom (Pleurotus ostreatus).[Prosiding] International Conference of Indonesia Forestry Researchers III-2015,671-81.

First Nature. 2014. Retrieved 5 April 2017 from www.first-nature.com/fungi/id-guide.php.

Harms H, Schlosser D, Lukas W. 2011. Untapped Potential: Exploiting Fungi in Bioremediation of Hazardous Chemicals.Nature Reviews Microbiology 9, 199-192. Pointing, Stephen B, Marilen M Parungao, and Kevin D Hyde. 2003. "Production of Wood-Decay Enzymes, Mass Loss and Lignin Solubilization in Wood by Tropical Xylariaceae Production of Wood-Decay Enzymes , Mass Loss and Lignin Solubilization in Wood by Tropical Xylariaceae.” Mycological Research 107 (2), 231-35.

Holmberg,Pelle , Marklund H. 1996.Helsinki:Otava Press.

Korhonen, Jarkko.2016.Sieniopas.Helsinki:Bookwell

Kosonen, Lasse.1994.Sienikirja.Helsinki:Graafiset Laitokset.

Li, S, T Zhu, G Liu, and H Zhu. 2012. Diversity of Macrofungal Community in Bifeng Gorge: The Core Giant Panda Habitat in China. African Journal of Biotechnology 11 (8): 1970-76.

Prasetyaningsih A, Rahardjo D. 2015. Keanekaragaman dan Potensi Makrofungi Taman Nasional Gunung Merapi [Prosiding] The 2 nd University Research Coloquium 2015, 471-481.

Ramírez LI, Junghanns C, Soto NO, Chávez DL, Luna CH, Demarche P, Enaud E, Morales RG, Agathos SN, Parra R. 2014. Journal of Molecular Catalysis B: Enzymatic Purification and Characterization of Two Thermostable Laccases from Pycnoporus Sanguineus and Potential Role in Degradation of Endocrine Disrupting Chemicals.Journal of Molecular Catalysis. B, Enzymatic" 108. Elsevier B.V.: 32-42. doi:10.1016/j.molcatb.2014.06.006. 
Sa'id G, Aditya AR. 2012. Jamur. Jakarta: Agriflo.

Sinaga MS. 2005. Jamur Merang Dan Budidayanya. Jakarta:Penebar Swadaya.

Sysouphanthong P, Thongkantha S, Zhao R, Soytong K, Kevin HD. 2010. Mushroom Diversity in Sustainable Shade Tea Forest and the Effect of Fire Damage.Biodivers Conserv 19,1401-15.

Tampubolon, SDB, Utomo B, Yunasfi. 2013. Keanekaragaman Jamur Makroskopis Di Hutan Pendidikan Universitas Sumatera Utara Desa Tongkoh Kabupaten Karo Sumatera Utara Peronema Forestry Science Journal 2(1), 176-82.

Uzan E, NousiainenP, Balland V, Sipila J, Piumi F, Navarro D, Asther M, Record E. 2010. "High Redox Potential Laccases from the Ligninolytic Fungi Pycnoporus Coccineus and Pycnoporus Sanguineus Suitable for White Biotechnology:From Gene Cloning to Enzyme Characterization and Applications. Journal of Applied Microbiology 108, 2199-2213.

Van der Wal A, Geydan TD, Kuyper TW, De Boer W. 2017. A Thready Affair: Linking Fungal Diversity and Community Dynamics to Terrestrial Decomposition Processes.FEMSMicrobiology Review 37 (4), 477-94.

Zhou X, Lin J, Jin Y, Zhao J, Sun X, and Tang K. 2007. Ganodermataceae : Natural Products and Their Related Pharmacological Functions. American Journal oF Chinese Medicine 35 (4), 559-74. 